Leading Article

\title{
Drug and non-thyroid induced changes in thyroid function tests
}

\author{
Ian Ramsay
}

Department of Endocrinology, North Middlesex Hospital, London N18 1QX, UK.

The basis of good medicine is a careful history and a thorough examination, supplemented by a minimum of tests to confirm the diagnosis. There is, however, an increasing tendency to perform screening tests just in case (Bahemuka \& Hodkinson, 1975; Hodkinson \& Denham, 1977). Screening tests for thyroid disease are particularly fraught with difficulty, since there are at least 11 different tests available, each of them capable of being carried out by several different techniques and the results of each of them can be subject to alteration in one direction or another by non-thyroidal disease or by drug therapy, as illustrated by an article in this issue (Wilkins et al., 1985).

Thyroxine $\left(\mathrm{T}_{4}\right)$ is the main hormone secreted by the thyroid gland. Once in the circulation most of it is bound to thyroxine-binding globulin (TBG), a lesser amount of thyroxine-binding pre-albumin (TBPA) and albumin and a small fraction $(0.05 \%)$ remains in the free form. Peripherally $25 \%$ of the $\mathrm{T}_{4}$ is monodeiodinated to form the more active hormone triiodothyronine $\left(\mathrm{T}_{3}\right)$, though a small amount of $T_{3}$ is also secreted directly by the thyroid gland. $T_{3}$, like $T_{4}$, is bound to the above mentioned proteins, though less so than $T_{4}$. The main effects of non-thyroid illness and of drugs are on the binding proteins, the degree of binding and on the conversion of $T_{4}$ to $T_{3}$. Changes in any of these may alter thyroid function tests and lead to misleading diagnoses of either hyper- or hypothyroidism.

The most commonly seen abnormality in clinical practice is the rise in total $T_{4}$ and $T_{3}$ in women who are pregnant or who are on oral contraceptives; this is caused by an oestrogen-dependent rise in TBG and thus in total hormone bound to it. A measurement of the free thyroxine index $\left(\mathrm{FT}_{4} \mathrm{I}\right)$ or of free thyroxine $\left(\mathrm{fT}_{4}\right)$ measured by equilibrium dialysis will be normal in euthyroid patients on oral contraceptives, but it should be noted that in pregnant patients, particularly in the third trimester, the $\mathrm{FT}_{4} \mathrm{I}$ may be slightly elevated (Ramsay, 1984) and the $\mathrm{fT}_{4}$ and $\mathrm{fT}_{3}$ may be below the

Correspondence: I. Ramsay, M.D., F.R.C.P., F.R.C.P.E.

Received: 15 November 1984 normal non-pregnant range (Ramsay, 1984). Drugs other than oestrogens which may cause rises in $T_{4}$ and $\mathrm{T}_{3}$ due to increased binding include clofibrate, 5fluorouracil, heroin and methadone (Wenzel, 1981). A small number of patients may have an increased amount of TBG due to porphyria (Kaplan, 1984) or as an inherited familial disorder (Jones \& Seal, 1967).

Reduced amounts of $\mathrm{T}_{4}$ and $\mathrm{T}_{3}$ in the blood may be due to a low level of TBG. This may be either familial or due to diseases such as Cushing's syndrome, acromegaly and nephrotic syndrome (Kaplan, 1984). A drug-induced reduction in the binding proteins may also occur; the drugs responsible are androgens, anabolic steroids and danazol (Graham \& Gambrell, 1980; Wenzel, 1981), but the commonest cause is a drug-induced inhibition of binding, most often due to fenclofenac (Ratcliffe et al., 1980), though this drug has now been withdrawn from the UK market. Other drugs which can produce the same phenomenon are diazepam, heparin, phenylbutazone, salicylates, sulphonylureas (Wenzel, 1981), halofenate and o-p' DDD (Kaplan, 1984).

Another mechanism by which levels of $T_{4}$ and $T_{3}$ may be reduced by drugs is by enzyme induction in the liver. The drugs involved are those used in the treatment of epilepsy and include carbamazepine, phenobarbitone, phenytoin and primidone (Larsen et al., 1970; Heyma et al., 1977; Wenzel, 1981).

Both iodide and lithium inhibit the release of thyroid hormones from the thyroid and may lead to low levels of $\mathrm{T}_{4}$ and actual clinical hypothyroidism, particularly in those who are genetically susceptible to thyroid autoimmune disease (Braverman et al., 1971; Spaulding et al., 1977). Amiodarone, which contains large amounts of iodine, can do the same thing or conversely may cause an iodide-induced thyrotoxicosis in a patient who is predisposed to Graves' disease or who has an autonomously functioning multinodular goitre (McKenna et al., 1983). Other effects of amiodarone are discussed below. Sodium nitroprusside and co-trimoxazole have a slight thyroid inhibiting effect and may cause lowered $\mathrm{T}_{4}$ levels (Wenzel, 1981). Somatostatin has a similar effect, 
though via inhibition of TSH release by the pituitary (Wenzel, 1981).

Although $\mathrm{T}_{4}$ levels are sometimes reduced in euthyroid hospital in-patients (Gooch et al., 1982), because of low levels of binding proteins, it is more common to find increased $T_{4}$ in this population (Mankikar and Clark, 1981; Gooch et al., 1982). The cause is either a high TBG which is familial or due to pregnancy, oestrogens, chronic active hepatitis (Schussler et al., 1978), primary biliary cirrhosis (Schussler et al., 1978) and acute intermittent porphyria or to collagen disease and myeloma (Kaplan, 1984).

In many acutely or chronically ill euthyroid patients a slight rise in $\mathrm{T}_{4}$ is due to inhibition of the peripheral conversion of $T_{4}$ to $T_{3}$. There are reduced $T_{3}$ levels (Bermudez et al., 1975; Gooch et al., 1982) and an increase in the inactive hormone reverse $\mathrm{T}_{3}\left(\mathrm{rT}_{3}\right)$. These changes are seen in febrile states, renal failure, anorexia nervosa, cirrhosis, disseminated malignancy and following surgery (Cavalieri \& Rapoport, 1977). However, it is important to note that $\mathrm{T}_{3}$ levels are normally lower in old age than in the young (Cavalieri \& Rapoport, 197). Similar slight rises in $\mathrm{T}_{4}$ with reduction in $\mathrm{T}_{3}$ and an increase in $\mathrm{rT}_{3}$ may be found with amiodarone (Burger et al., 1976), sodium iopodate for oral cholecystography (Bürgi et al., 1976; Wu et al., 1978; Beng et al., 1980), propranolol and certain other $\beta$-adrenergic receptor blockers (Kristensen \& Weeke, 1977; Cooper et al., 1982; Perrild et al., 1983), high dose glucocorticoids, iobenzamic acid and tyropanoic acid (Wenzel, 1981). Propylthiouracil (Geffner $e t$ al., 1975) and iodide will tend to reduce the $\mathrm{T}_{4}$ also because of a direct inhibiting effect on the thyroid gland.

How then is one to sort out whether a patient with an abnormal $T_{4}$ or $T_{3}$ has or has not got thyroid disease? Direct measurement of $\mathrm{fT}_{4}$ or $\mathrm{fT}_{3}$ by radioimmunoassay after equilibrium dialysis will be normal in most circumstances but note that $\mathrm{fT}_{4}$ can be elevated by sodium iopanate (Bürgi et al., 1976), propranolol c. (Kristensen \& Weeke, 1977.; Cooper et al., 1982; Wilkinson et al., 1985 this issue) and acetylsalicyclic acid (Langer et al., 1978) and decreased by phenytoin (Larsen et al., 1970), phenylbutazone (Abiodun et al., 1973) and fenclofenac (Humphrey et al., 1980). Likewise the $\mathrm{fT}_{3}$ can be reduced by sodium iopadate (Beng et al., 1980), amiodarone (Burger et al., 1976), propranolol (Wilkins et al., 1985), in pregnancy (Ramsay, 1984), fever, renal failure, following surgery, cirrhosis and disseminated malignancy (Cavalieri \& Rapoport, 1977).

In most cases where hypothyroidism is suspected because of low thyroid hormone results, but the patient is really euthyroid, the basal thyroid stimulating hormone (TSH) levels will be within the normal range. Borderline high TSH results can be sorted out by means of the thyrotrophin releasing hormone (TRH) test (Hall et al., 1973) when an exaggerated response will suggest hypothyroidism, particularly if thyroid antibodies are also present. The TRH test is also useful in the converse situation, that of suspected hyperthyroidism. A flat response of TSH to TRH (Hall et al., 1973) is compatible with the diagnosis. Th8 only situation in which one might get a drug-induce flat response is if a patient is on high dose (e.g. $8 \mathrm{mg}$ dexamethasone (Cavalieri \& Rapoport, 1978). Eve here the response in a euthyroid patient is not completely flat (Wenzel, 1981) and a normal response can be achieved by increasing the dose of TRH (Otsuki et al., 1973).

\section{References}

ABIODUN, M.O., BIRD, R., HAVARD, C.W.H. \& SOOD, N.K. (1973). The effects of phenylbutazone on thyroid function. Acta Endocrinologica, 72, 257.

BAHEMUKA, M. \& HODKINSON, H.M. (1975). Screening for hypothyroidism in elderly inpatients. British Medical Journal, 2, 601.

BENG, C.G., WELLBY, M.L., SYMONS, R.G., STUART, S. \& MARSHALL, J. (1980). The effects of iopodate on the serum iodothyronine pattern in normal subjects. Acta Endocrinologica, 93, 175.

BERMUDEZ, F., SURKS, M.I. \& OPPENHEIMER, J.H. (1975). High incidence of decreased serum triiodothyronine concentration in patients with nonthyroidal disease. Journal of Clinical Endocrinology and Metabolism, 41, 27.

BRAVERMAN, L.E., INGBAR, S.H., VAGENAKIS, A.G., ADAMS, L. \& MALOOF, F. (1971). Enhanced susceptibility to iodide myxedema in patients with Hashimoto's disease. Journal of Clinical Endocrinology and Metabolism, 32, 515.

BURGER. A.. DINICHERT. D.. NICOD. P.. JENNY. M..

LEMARCHAND-BÉRAUD, T. \& VALLOTTON, M.B. (1976). Effect of amiodarone on serum triiodothyronine, reverse triiodothyronine, thyroxin and thyrotropin. Journal of Clinical Investigation, , 58, 255.

BÜRGI, H., WIMPFHEIMER, C., BURGER, A., ZAUNBAUER, W., RÖSLER, H. \& LEMARCHAND-BÉRAUD, T. (1976). Changes in circulating thyroxine, triiodothyronine and reverse triiodothyronine after radiographic contrast agents. Journal of Clinical Endocrinology and Metabolism, 43, 1203.

CAVALIERI, R.R. \& RAPOPORT, B. (1974). Impaired peri- N pheral conversion of thyroxine to triiodothyronine. Annual Review of Medicine, 28, 57.

COOPER, D.S., DANIELS, G.H., LADENSON, P.W. \& RIDGWAY, E.C. (1982). Hyperthyroxinemia in patients treated with high dose propranolol. American Journal of Medicine, 73, 867.

GEFFNER, D.L., AZUKIZAWA, M. \& HERSHMAN, J.M. (1975). Propylthiouracil blocks extrathyroidal conversion 
of thyroxine to triiodothyronine and augments thyrotropin secretion in man. Journal of Clinical Investigation, 55, 224.

GOOCH, B.R., ISLEY, W.L. \& UTIGER, R.D. (1982). Abnormalities in thyroid function tests in patients admitted to a medical service. Archives of Internal Medicine, 142, 1801.

GRAHAM, R.L. \& GAMBRELL, R.D. (1980). Changes in thyroid function tests during danazol therapy. Obstetrics and Gynecology, 55, 395.

HALL, R., EVERED, D.C. \& TUNBRIDGE, W.M.G. (1973). The role of TSH and TRH in thyroid disease. In 9th Symposium on Advanced Medicine, Walker, G. (ed.) pp. 15-26, Pitman Medical: London.

HEYMA, P., LARKINS, R.G., PERRY-KEENE, D., PETER, C.T., ROSS, D. \& SLOMAN, J.G. (1977). Thyroid hormone levels and protein binding in patients on long-term diphenylhydantoin treatment. Clinical Endocrinology, 6, 369.

HODKINSON, H.M. \& DENHAM, M.J. (1977). Thyroid function tests in the elderly in the community. Age and Ageing, $6,67$.

HUMPHREY, M.J., CAPPER, S.J. \& KURTZ, A.B. (1980). Fenclofenac and thyroid hormone concentrations. Lancet, i, 487.

JONES, J.E. \& SEAL, U.S. (1967). X-chromosome linked inheritance of elevated thyroxine-binding globulin. Journal of Clinical Endocrinology and Metabolism, 27, 1521.

KAPLAN, M.M. (1984). Thyroid hormones. In Endocrine Disorders: a Guide to Diagnosis, R.A. Donald (ed.) Marcel Dekker, New York.

KRISTENSEN, B.O. \& WEEKE, J. (1977). Propranolol-induced increments in total and free serum thyroxine in patients with essential hypertension. Clinical Pharmacology and Therapeutics, 22, 864.

LANGER, P., FÖLDES, O., MICHAJLOVSKI, N., JEŽOVÁ, D., KLIMEŚ, I., MICHALKO, J. \& ZÁVADA, M. (1978). Shortterm effect of acetylsalicyclic acid analogue on pituitarythyroid axis and plasma cortisol levels in healthy volunteers. Acta Endocrinologica, 88, 698.

LARSEN, P.R., ATKINSON, A.J. JR., WELLMAN, H.N. \& GOLDSMITH, R.E. (1970). The effect of diphenylhydantoin on thyroxine metabolism in man. Journal of Clinical Investigation, 49, 1266.
MANKIKAR, G.D. \& CLARK, A.N.G. (1981). Euthyroid "thyroxine toxicosis". Journal of the American Geriatrics Society, 29, 331.

McKENNA, W.J., ROWLANDS, E. \& KRIKLER, D.M. (1983). Amiodarone: the experience of the past decade. British Medical Journal, 287, 1654.

OTSUKI, M., DAKODA, M. \& BABA, S. (1973). Influence of glucocorticoids on TRF-induced TSH response in man. Journal of Clinical Endocrinology and Metabolism, 36, 95.

PERRILD, H., HANSEN, J.M., SKVOSTED, L. \& CHRISTENSEN, L.K. (1983). Different effects of propranolol, alprenolol, sotalol, atenolol and metoprolol on serum $\mathrm{T}_{3}$ and serum $\mathrm{rT}_{3}$ in hyperthyroidism. Clinical Endocrinology, 18, 139.

RAMSAY, I. (1984). Thyroid disease. In Medical Disorders in Obstetric Practice, M. de Swiet (ed.), pp. 385-404. Blackwell Scientific Publications, Oxford.

RATCLIFFE, W.A., HAZELTON, R.A., THOMSON, J.A. \& RATCLIFFE, J.G. (1980). The effect of fenclofenac on thyroid function tests in vivo and in vitro. Clinical Endocrinology, 13, 569.

SCHUSSLER, G.C., SCHAFFNER, F. \& KORN, F. (1978). Increased serum thyroid hormone binding and decreased free hormone in chronic active liver disease. New England Journal of Medicine, 299, 510.

SPAULDING, S.W., BURROW, G.N., RAMEY, J.N. \& DONABEDIAN, R.K. (1977). Effect of increased iodide intake on thyroid function in subjects on chronic lithium therapy. Acta Endocrinologica, 84, 290.

WENZEL, K.W. (1981). Pharmacological interference with in vitro tests of thyroid function. Metabolism, 30, 717.

WILKINS, M.R., FRANKLYN, J.A., WOODS, K.L. \& KENDALL, M.J. (1985). Effect of propranolol on thyroid homeostasis of healthy volunteers. Postgraduate Medical Journal, 61, 391.

WU, S-Y., CHOPRA, I.J., SOLOMON, D.H. \& JOHNSON, D.E. (1978). The effect of repeated administration of ipodate (Orografin) in hyperthyroidism. Journal of Clinical Endocrinology and Metabolism, 47, 1358. 